\title{
INVESTMENT IN RESEARCH AND DEVELOPMENT FOR BASMATI RICE IN PAKISTAN
}

Environment, Natural Resources, and Agriculture Division, Central and West Asia Department

NO. 7

December 2018

\section{ADB CENTRAL AND WEST ASIA WORKING PAPER SERIES}





\section{ADB Central and West Asia Working Paper Series}

\section{Investment in Research and Development for Basmati Rice in Pakistan}

Environment, Natural Resources, and Agriculture Division, Central and West Asia Department No.7 | December 2018 
(C) 2018 Asian Development Bank

6 ADB Avenue, Mandaluyong City, 1550 Metro Manila, Philippines

Tel +632632 4444; Fax +6326362444

www.adb.org

Some rights reserved. Published in 2018.

ISSN 2313-7355 (print), 2313-7363 (electronic)

Publication Stock No. WPS189710-2

DOI: http://dx.doi.org/10.22617/WPS189710-2

The views expressed in this publication are those of the authors and do not necessarily reflect the views and policies of the Asian Development Bank (ADB) or its Board of Governors or the governments they represent.

ADB does not guarantee the accuracy of the data included in this publication and accepts no responsibility for any consequence of their use. The mention of specific companies or products of manufacturers does not imply that they are endorsed or recommended by ADB in preference to others of a similar nature that are not mentioned.

By making any designation of or reference to a particular territory or geographic area, or by using the term "country" in this document, $A D B$ does not intend to make any judgments as to the legal or other status of any territory or area.

This work is available under the Creative Commons Attribution 3.0 IGO license (CC BY 3.0 IGO)

https://creativecommons.org/licenses/by/3.0/igo/. By using the content of this publication, you agree to be bound by the terms of this license. For attribution, translations, adaptations, and permissions, please read the provisions and terms of use at https://www.adb.org/terms-use\#openaccess.

This CC license does not apply to non-ADB copyright materials in this publication. If the material is attributed to another source, please contact the copyright owner or publisher of that source for permission to reproduce it. $\mathrm{ADB}$ cannot be held liable for any claims that arise as a result of your use of the material.

Please contact pubsmarketing@adb.org if you have questions or comments with respect to content, or if you wish to obtain copyright permission for your intended use that does not fall within these terms, or for permission to use the ADB logo.

Notes:

In this publication, "\$” refers to United States dollars.

Corrigenda to ADB publications may be found at http://www.adb.org/publications/corrigenda. 


\section{CONTENTS}

TABLES, FIGURES, AND BOX iv

ABSTRACT V v v v v

ACKNOWLEDGMENTS vi

CURRENCY EQUIVALENT Vii

ABBREVIATIONS vii

$\begin{array}{ll}\text { I. INTRODUCTION } & 1\end{array}$

II. PAKISTAN'S RICE PRODUCTION AND EXPORTS 2

III. PAKISTAN'S BASMATI RICE PRODUCTION AND EXPORTS 4

IV. PAKISTAN'S AGRICULTURE RESEARCH INSTITUTES

$\begin{array}{lll}\text { V. } & \text { AGRICULTURE RESEARCH AND DEVELOPMENT } & 7\end{array}$

VI. $\quad$ BASMATI RICE RESEARCH AND DEVELOPMENT 13

$\begin{array}{ll}\text { VII. } & \text { CONSEQUENCES OF LIMITED RESEARCH AND DEVELOPMENT } \\ \text { BUDGET FOR BASMATI RICE } & 15\end{array}$

VIII. EMPIRICAL ANALYSIS OF THE IMPACT OF RESEARCH AND DEVELOPMENT ON BASMATI EXPORTS 18

IX. $\quad$ CONCLUSION AND POLICY RECOMMENDATIONS 22

$\begin{array}{ll}\text { REFERENCES } & 25\end{array}$ 


\section{TABLES, FIGURES, AND BOX}

\section{TABLES}

1 Rice Production in Pakistan, 2014-2015 4

2 Expenditure on Rice Research at Government Institutes 14

3 Rice Yield Gaps in Pakistan 18

4 Summary Statistics for the Vector Autoregression Indicators 19

5 Dickey-Fuller Tests for a Unit Root 20

6 VAR-X Model for Export Volume and Value 21

\section{FIGURES}

1 Global Rice Production Areas and Exports, 1960-2016 3

2 Pakistan Basmati Rice: Area, Yield, and Production, 1997-2014 5

3 Agriculture R\&D Spending as a Share of Agriculture GDP, 2000-2012 9

4 Total Agriculture R\&D Spending per 100,000 Farmers, 2000-2012 10

5 Researchers per 100,000 Farmers, 2000-2012 11

6 Share of Agriculture R\&D, Government and Higher Education Institutions, India and Pakistan 12

7 Export Volume and Value of Pakistan's Basmati and Nonbasmati Rice, 2001-2015 16

8 International Price of Pakistan's Basmati and Nonbasmati Coarse Rice, 2001-2015 17

9 Log Values of the Vector Autoregression Variables, 1997-2014 19

10 Impulse Response Functions for the VAR-X Model for the Value of Basmati Rice Exports from Pakistan

\section{BOX}

Excerpts from the Economic Survey of Pakistan 


\section{ABSTRACT}

Basmati rice is Pakistan's celebrated export. After years of growth, Pakistan's production and export of basmati has slipped and is on a downward trend. The absence of a strong research and development institutional structure makes it extremely difficult for the sector to prepare for new challenges. The status of basmati rice as a major export commodity hides the fact that its contribution is below its potential. Without a policy commitment to elevate basmati rice as a strategic product, it will continue to be impacted by changing economic and environmental conditions. Extra funding for basmati can be easily channeled from the levy that is being collected from its export or through government development funds. The bigger challenge is changing the embedded mindset that fails to connect research and development with the production and commercialization of basmati.

Keywords: basmati rice, Pakistan, rice export, agriculture R\&D JEL classification codes: Q16, Q17, O13 


\section{ACKNOWLEDGMENTS}

This working paper was prepared under Asian Development Bank (ADB) technical assistance (TA), TA 8578-PAK: Punjab Basmati Rice Value Chain by the Environment, Natural Resources, and Agriculture Division (CWER) of ADB's Central and West Asia Department. The report was written by Kiyoshi Taniguchi (corresponding author: ktaniguchi@adb.org, principal economist, ADB's Economic Analysis and Operational Support Division of the Economic Research and Regional Cooperation Department) and Sahibzada Mansoor Ali (agriculture value chain specialist and TA consultant), with inputs from Noriko Sato (natural resources specialist, CWER) and Akmal Siddiq (chief of the ADB Rural Development and Food Security Thematic Group, Sustainable Development and Climate Change Department). Research assistance was provided by Shine Cagas and Daryll Naval (TA consultants). Editorial support was provided by Jill Gale de Villa (editing specialist and TA consultant). 


\title{
CURRENCY EQUIVALENT
}

\author{
Currency Unit - Pakistan rupees (PRs) \\ PRs1.00 $=\$ 0.0098$ \\ $\$ 1.00=$ PRs101.725
}

25 June 2015

\section{ABBREVIATIONS}

$\begin{array}{ll}\text { AARI } & \text { Ayub Agricultural Research Institute } \\ \text { AREF } & \text { Agricultural Research Endowment Fund } \\ \text { GDP } & \text { gross domestic product } \\ \text { IRRI } & \text { International Rice Research Institute } \\ \text { MOC } & \text { Ministry of Commerce } \\ \text { MOF } & \text { Ministry of Finance } \\ \text { MPOB } & \text { Malaysian Palm Oil Board } \\ \text { PARB } & \text { Punjab Agricultural Research Board } \\ \text { PARC } & \text { Pakistan Agricultural Research Council } \\ \text { PPP } & \text { public-private partnership } \\ \text { R\&D } & \text { research and development } \\ \text { RRI } & \text { Rice Research Institute } \\ \text { VAR } & \text { vector autoregression }\end{array}$





\section{INTRODUCTION}

Insufficient investment in agriculture research and development (R\&D) in Pakistan has resulted in suboptimal yields and a lower-than-potential productivity growth curve of its basmati rice varieties. Pakistan is the globe's fourth largest rice ${ }^{1}$ exporter in terms of quantity, ${ }^{2}$ and rice is the country's second largest export earner, after cotton. ${ }^{3}$ This status was achieved by liberalizing the rice trade in the early 1990s and allowing the private sector to operate freely. The one-off effect of this liberalization catapulted the commodity to its current export status. However, once the initial effect wore off, the productivity, export, and value added of Pakistani rice varieties, especially of basmati, stagnated. In the last decade, the growth of Pakistan's overall rice export growth has remained unchanged and, in the case of basmati, has dropped significantly.

Pakistan's current rice production (including of basmati) is impacted by external factors and competing varieties. Lack of investment in R\&D of basmati is a major factor in the country's inability to prepare for changing environmental and market conditions for the variety. The R\&D deficiency places the rice sector in a reactive position, rather than proactively preparing for shifting dynamics. Changing market dynamics mean that basmati is no longer the only premium variety for international buyers. Newer longgrain, nonaromatic varieties have been cutting into basmati's share of the premium rice market. Lowvalue, nonbasmati varieties can still thrive by catering to low-priced, lower-quality markets but premium varieties require greater $R \& D$ investment to maintain their edge.

This challenge may also be a symptom of the lack of policy commitment. During interviews, policy makers seemed to regard rice as such a success story that further investment in it is thought unnecessary. Liberalization of trade was also taken to mean that the state had no more responsibility for serious R\&D of basmati. In the last 10 years, the government has focused significantly on developing horticulture, livestock, fisheries, and forestry, as grain crops had already received significant development resources. Successful examples can be cited from around the world, where countries have spent large amounts and devoted large shares of resources on their chosen "champion" products (e.g., palm oil in Malaysia). Given basmati's high market value and potential to expand exports, it should be a major strategic commodity of focus for the government. However, policy makers do not appear to appreciate the importance of promoting basmati.

Underinvestment does not necessarily mean low levels of funding but can also be manifest in misaligned utilization of resources. Pakistan's R\&D in rice is structured in the same way as its R\&D for all agriculture research: a supply-driven instead of demand-driven system that excludes farmers, industry, businesses, and service providers from the determination of the research agenda and results in a lack of incentives for innovative research and a lack of motivation among stakeholders to participate in R\&D efforts and other reforms.

This paper focuses primarily on basmati rice. However, many points of the discussion are equally applicable to other rice varieties. The word "rice" is used to include all rice varieties.

2 Food and Agriculture Organization of the United Nations (FAO) Statistical Database (FAOSTAT) on Crops and Livestock Products. 2016. http://www.fao.org/faostat/en/\#data/TP (accessed 30 October 2018).

3 State Bank of Pakistan. Export Receipts by Commodity. http://www.sbp.org.pk/ecodata/Export_Receipts_by_Commodity. xls (accessed 21 October 2018). 
This falls short of the modern approach - an integrated strategy for R\&D and commercialization that provides a more productive result. Such an approach may not be suitable for all commodities, but should be preferred for star commodities such as basmati. The principle of "farming-for-the-market" would dictate that strategic decisions should be influenced by demand factors. But even with such an approach, an efficient policy, strategy, and R\&D framework is still required. By innovatively streamlining R\&D, from seed development to export markets, Pakistan can achieve the maximum value addition from this crop.

As noted later, Pakistan spends less than its comparators on agriculture R\&D. The country is effectively riding on research done elsewhere and has limited influence on international markets and customer demands. The case for increasing funding is clear-cut and is acknowledged by the federal and Punjab government vision documents. ${ }^{4}$ In fact, shortage of funds is not really an issue, especially in Punjab, Pakistan's largest province, where most of the premium rice is grown. However, any increase in funding will still go through the existing R\&D setup and channels with some new approaches at the margins, rather than addressing the need to treat basmati rice as a special strategic asset and committing the government to maximize its export quality, quantity, and price. Rice exporters' contribution to a cess fund is considerable but is lost in the overall federal treasury system and not plowed back into rice value chains. ${ }^{5}$ A commitment to allocate R\&D funding for the complete value chain under one umbrella would herald a new period of growth for basmati.

Changing market dynamics mean that basmati is no longer the only premium variety for international buyers. Newer long-grain, nonaromatic varieties have been cutting into basmati's share of the premium rice market. The principle of "farming-for-the-market" would dictate that strategic decisions should be influenced by demand factors. But even with such an approach, an efficient policy, strategy, and R\&D framework is required. In the absence of such an approach, Pakistan's current rice production (including of basmati) is impacted by external factors and competing varieties. The country is effectively riding on research done elsewhere and has limited influence on international markets and customer demands.

\section{PAKISTAN'S RICE PRODUCTION AND EXPORTS}

Rice is a major global grain crop, and its total production, cultivated area, and exports continue to increase (Figure 1). The overall global prospects of the commodity make it an important cereal crop.

Rice is Pakistan's largest food export and second largest agriculture export after cotton. ${ }^{6}$ Pakistan is among the globe's top five rice exporters and is the 10th largest rice producer. The deregulation of the rice trade by the government in the early 1990s was a success, as the commodity became a celebrated and consistent foreign exchange earner for Pakistan.

$4 \quad$ Planning Commission of Pakistan. 2014. Pakistan Vision 2025. Islamabad; Government of Punjab. 2015. Punjab Growth Strategy 2018. Lahore.

5 A "cess" is a tax or levy imposed by the government for a specific purpose and is based on some assessment of value.

6 Wheat, not rice, is Pakistan's staple food. 


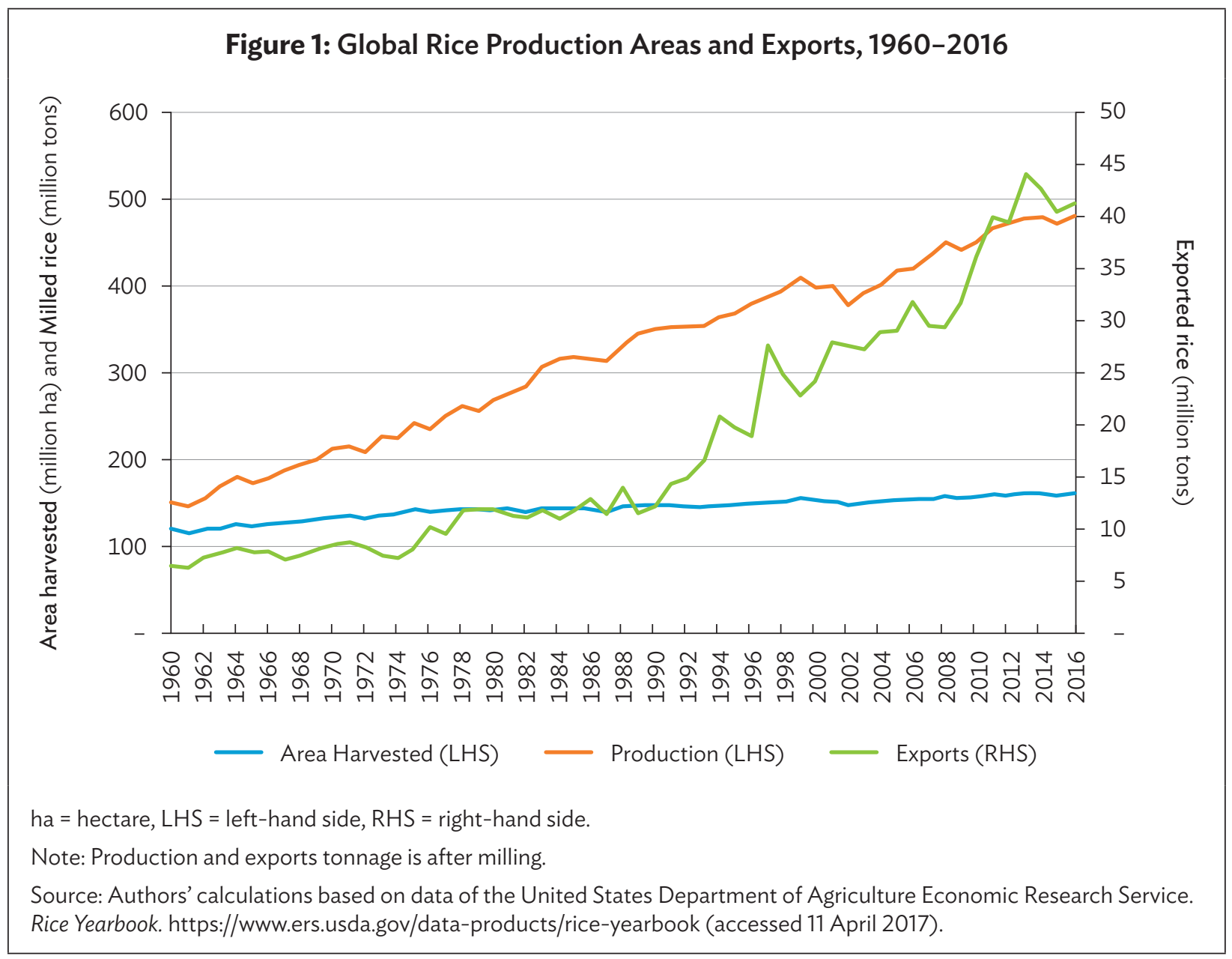

Pakistan's rice production and export (Table 1) can be divided in two broad categories: basmati and nonbasmati (all types of rice). Basmati is the long-grain aromatic rice peculiar to certain districts of Punjab Province. Nonbasmati varieties primarily comprise varieties developed by the International Rice Research Institute (IRRI) - IRRI6 and IRRI9-which are nonaromatic and shorter grain than basmati. The nonbasmati classification now also includes long-grain nonaromatic varieties that are directly competing with basmati.

Because nonbasmati varieties are not restricted to specific areas for cultivation, their production area and quantity have increased considerably over the years. Basmati production, on the other hand, has not been grown successfully outside its traditional area, and some of the traditional basmati area has now been planted with long-grain nonaromatic varieties that are in the same price range as basmati and thus are now a direct threat to the basmati heartland. Basmati is unique to some districts of Punjab province. IRRI varieties are predominantly grown in Sindh province. There is, however, some overlap of each variety in the border districts. In terms of production volume, the locally available IRRI varieties of coarse rice dominate. Although in terms of tonnage, nonbasmati rice varieties account for $65 \%$ of Pakistan's total rice production, they represent only $35 \%$ of its monetary value. 
Table 1: Rice Production in Pakistan, 2014-2015

\begin{tabular}{lcccc}
\hline Rice & $\begin{array}{c}\text { Area } \\
(' 000 \text { ha })\end{array}$ & $\begin{array}{c}\text { Production } \\
\text { ('O00 tons) }\end{array}$ & $\begin{array}{c}\text { Export } \\
(' 000 \text { tons })\end{array}$ & $\begin{array}{c}\text { Export Value } \\
(\$ \text { million })\end{array}$ \\
\hline Basmati & 1,424 & 2,548 & 619 & 681.55 \\
\hline IRRI & 780 & 2,180 & $2,746^{\mathrm{a}}$ & 981.32 \\
\hline Other Nonbasmati & 687 & 2,275 & 367 & 185.84 \\
\hline Total & $\mathbf{2 , 8 9 1}$ & $\mathbf{7 , 0 0 3}$ & 3,732 & $\mathbf{1 , 8 4 8 . 7 1}$ \\
\hline
\end{tabular}

ha = hectare, IRRI = International Rice Research Institute.

a The discrepancy between the production and export volumes between the IRRI varieties and nonbasmati varieties stems from the difference between the timing of the financial year and that of the crop year, and an overlap of previous stocks and the new crop.

Sources: Government of Pakistan, Bureau of Statistics. Agriculture Statistics of Pakistan 2014-2015, http://www.pbs.gov.pk/ content/agriculture-statistics (accessed 21 October 2018); Rice Exporters Association of Pakistan. Country Wise Position of Export of Basmati Rice July 2014 to June 2015. http://reap.com.pk/admincp/download/Upload_files/cw20142015.pdf (accessed 13 April 2018).

\section{PAKISTAN'S BASMATI RICE PRODUCTION AND EXPORTS}

Looking at the past 10 years of data shows that basmati production has been volatile (Figure 2). The successful increase of basmati production in the 2000 s can be attributed to factors including irrigation advances, new seed varieties, and export deregulation. Once the productivity gains from the one-off impact of improvement in these factors was achieved, subsequent growth rates declined due to a lack of follow-through.

India is Pakistan's only competitor in the export market for basmati rice, but basmati also has to compete with other varieties in the global marketplace. Although Pakistan inherited good rice varieties and managed to improve on them, during the last 20 years the country has not made significant progress in having new commercial varieties adopted by the market. One reason for this, as noted by stakeholders consulted by the authors, is that the quantity and quality of research done on basmati in Pakistan are deficient, especially compared to the work done by other countries (see section V). In addition, Pakistan's basmati production is challenged by factors including low yields, poor handling, old varieties, changing environmental factors, and diseases. Despite multiple issues, Pakistan continues to be a major global exporter. Any decline in Pakistan's basmati exports has a large proportional impact on the country's gross domestic product (GDP) and exports. As competitor countries improve the quality and quantity of the rice they produce and their rice value chains, Pakistan risks being left behind unless it follows suit. 


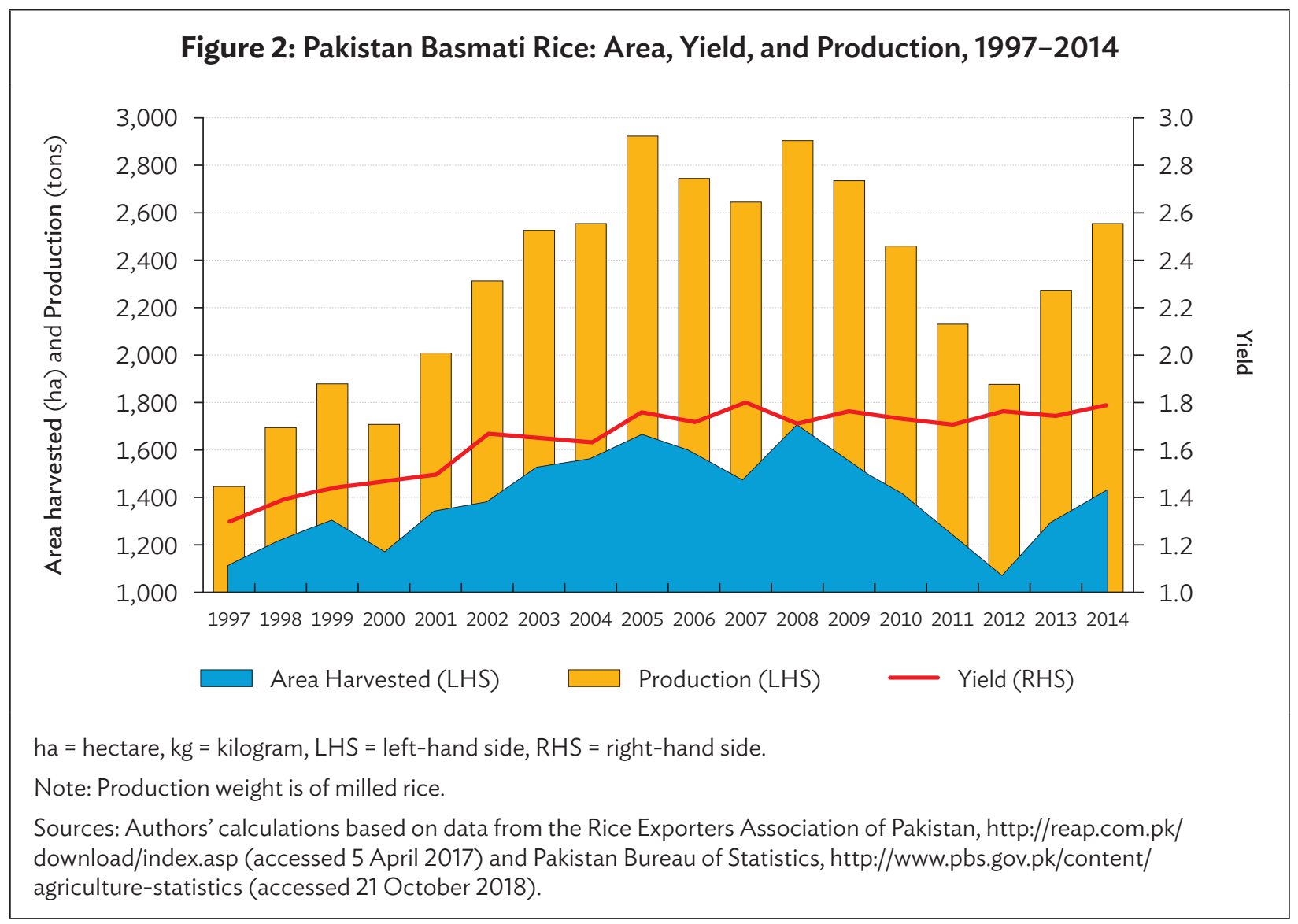

Basmati is only grown in specific areas of India and Pakistan. ${ }^{7}$ Being a niche variety with a relatively small gene pool, basmati requires more research than other varieties in order to increase its yields, protect it from disease, enhance its ability to compete with other varieties, and increase its resilience to climate and other environmental changes. Given basmati's specific genetic characteristics and environmental requirements, it may always have a lower yield than other varieties. However, the price premium it commands is large enough to compensate for the lower yields. Thus, because basmati fetches high prices in international markets, it can still be an attractive investment despite its relatively lower yields. Nevertheless, the lack of advances in basmati research is impacting its profitability and dampening the outlook for its future.

Organized R\&D on basmati started in the late 1920s and resulted in the approval of the basmati 370 variety as a historic benchmark in 1933. This variety was grown for more than 30 years until the mid-1960s, when the basmati 622 and Basmati Pak varieties were developed. The next round of development came in the 1980s, when basmati 385 was approved. The mid-1990s saw the approval of the super basmati variety. It continues to be the main variety, comprising more than $80 \%$ of all basmati currently cultivated in Punjab. In the last 10 years, newer varieties with higher yields have been developed but have not found wide commercial acceptance. Many new varieties have the essential basmati genes but the aroma traits are only expressed fully in specific districts of Punjab, due to the unique combination of water, soil, and climatic conditions. These features make the basmati cultivated in these areas in Punjab (known as the kallar tract) special. See Cheema, B. 2018. Basmati Rice-A Fragrant Heritage of Punjab, Pakistan. Presentation at the International Rice Congress, Singapore, 15-17 October 2018. 
The demand for the aromatic long-grain quality of basmati is being challenged by nonaromatic long-grain varieties that are higher yielding and show greater disease resistance. Prices for such varieties are in the same bracket as traditional basmati rice. In addition, the new nonaromatic varieties are often marketed using the basmati name. This is rightly disputed by many people in Pakistan who feel that the unique traits of basmati need to be preserved, its name should not be used on packaging of other varieties, and it should not be mixed with nonaromatic varieties for marketing purposes. However, the situation also shows how producers can shift the market toward a different variety by using the good name of an existing brand. In this area, Pakistan's research and marketing system is failing to respond adequately to challenges and threats from outside.

\section{PAKISTAN'S AGRICULTURE RESEARCH INSTITUTES}

The governance structure of agriculture research in Pakistan has been changing since 2010. Prior to 2010, the Federal Ministry of Food, Agriculture, and Livestock had the main responsibility for this area. The 18th constitutional amendment transferred many areas, including agriculture, from federal oversight to the provinces. Although no agriculture facilities or institutions have been closed, the removal of agriculture from federal control has downgraded the sector in terms of priority. A new Ministry of National Food Security and Research has been established and many of the previous federal institutes now come under it. At the same time, individual provinces now have greater responsibility for agriculture but are still in a transitional state in terms of improving their capacity to conduct independent policies.

A 2015 study by the International Food Policy Research Institute (IFPRI) noted that 209 public sector agencies are conducting agriculture research in Pakistan: 64 at the federal level, 114 at the provincial level, and 31 affiliated with universities. ${ }^{8}$ The principal agriculture R\&D agency is the Pakistan Agricultural Research Council (PARC). PARC has a wide mandate to coordinate research among federal, provincial, and higher education agencies. PARC operates 12 institutes and supervises several research agencies throughout the country. The National Agricultural Research Centre is one of the largest of the institutes under PARC and has a number of its own research institutes. PARC contributes about $13 \%$ to the country's total agriculture research output in terms of number of institutes. Some other federal agencies conduct agriculture R\&D administered by different ministries including those under the Pakistan Atomic Energy Commission. Together, these other federal agencies account for about $14 \%$ of Pakistan's agriculture research capacity. The private sector also does some agriculture research.

The Punjab Agricultural Research Board (PARB), a provincial entity, performs research, planning, and resource allocation functions. The Ayub Agricultural Research Institute (AARI) manages 28 croprelated research institutes and employs half of the province's agriculture researchers. Both the PARB and AARI are under the jurisdiction of the Punjab Agriculture Department. The AARI is the parent body of the Rice Research Institute (RRI), along with 27 other specialized institutes.

The higher education sector accounts for 15\% of Pakistan's agriculture research capacity and has seen considerable growth since the early 1990s, as the number of universities has increased. The University of Agriculture, Faisalabad is Pakistan's largest agriculture university. It includes the Division of Education and Extension and the Water Management Research Centre, and six other faculties that conduct

8 International Food Policy Research Institute (IFPRI). 2015. Agricultural R\&D Indicators Factsheet for Pakistan. Agricultural Science and Technology Indicators. Washington, DC. 
agriculture research. Other specialized agriculture universities include the Sindh Agriculture University, Tandojam; Agricultural University Peshawar; Pir Mehr Ali Shah Arid Agriculture University Rawalpindi; and University of Veterinary and Animal Sciences, Lahore. Some agriculture research is also done in departments of other universities with focus on specific commodities.

Agriculture, by its nature, requires long-term vision and planning, as does R\&D. Hence, investment in agriculture $R \& D$ requires consistent and long-term commitment. The agriculture sector needs a unified strategy to avoid fragmentation. However, the large number of agriculture research organizations and institutions in the country indicates there is significant fragmentation. Devolution of agriculture to the provinces after the 18th constitutional amendment has further fragmented the system and its associated R\&D activities.

The role of the private sector in agriculture research in Pakistan is growing, as companies conduct their own research. However, seed companies in Pakistan are reluctant to invest in research because legislation is insufficient to protect intellectual property and plant breeders' rights. There are also no tax incentives to support private sector R\&D. Hence, some companies focus solely on importing and doing research on hybrid seeds. Here again, basmati is at a disadvantage versus other varieties due to the late start of hybrid research on basmati and technical issues that require time and resources to ensure the preservation of aromatic characteristics in new higher-yielding, disease-resistant basmati varieties. Due to cost factors and commercial interests, the private sector is less inclined to engage in research on basmati than on other varieties that have a longer research track record in several countries. Research on basmati can only be conducted in the basmati growing areas of Pakistan and India, whereas research on competitor varieties can benefit from multinational efforts in many sites. Enforcing intellectual property rights could increase the private sector's motivation to do research and thus reduce the need for increased investment from the public sector.

Another major impediment to the commercial development of new varieties is the increasing difficulty of obtaining approval for new crop varieties since the 2010 devolution of agriculture to the provinces. Provincial government-run seed councils in charge of approving new varieties are faced with the competing claims of public and private institutions applying for certifications. Further, research institutes lack capacity for producing pre-basic and basic seeds, which in turn hinders the large-scale commercial production needed to adequately disseminate new seed varieties.

\section{AGRICULTURE RESEARCH AND DEVELOPMENT}

Pakistan's agriculture sector has been performing at a suboptimal level for many years. The underlying factor is the absence of an overall strategic vision and policy that views the agriculture sector as a whole, including the downstream portions of the value chain: processing and export. The lack of a championing entity responsible for the whole value chain leads to fragmented resource allocations and a mismatch between what the market needs and what the seed breeders and farmers produce.

Annual analysis of the rice subsector, especially of basmati, may provide an overall picture; however, such analysis may not show the gap between the current level of achievement and the potential. This gap points to inefficiency or underinvestment of resources that could otherwise have been used to improve productivity. 
The annual Economic Survey of Pakistan provides a glimpse into priority areas for policy makers. A reading of its chapters on agriculture from 2014 to 2017 shows that investment in R\&D is not considered a priority (Box). In fact, a word search for R\&D in chapters relating to agriculture comes up with no results. The excerpts in the box show that, in the absence of an anchoring policy, targets and areas of focus change every year. The focus is often on specific interventions being funded in a particular year without reference to an overarching policy road map.

\section{Box: Excerpts from the Economic Survey of Pakistan}

The following are from the agriculture chapters of the Economic Survey of Pakistan, and illustrate the lack of focus on research and development.

The rapid growth of Pakistan's urban areas indicate that demand for high-value perishable products such as fruits, vegetables, dairy, and meat is rising. Government is focusing to increase the yield for rural growers through major infrastructure investments including reliable transport networks and other building blocks for modern supply chains. CPEC will go a long way in the enhancement of agribusiness benefits by tapping value-added product innovation and supply chain. ${ }^{a}$

The government is focusing on improving agricultural productivity by increasing crops yield, systematic application of better inputs and advance technology to enhance profitability of the farming community, improve competitiveness and ensure the environmental sustainability of agriculture. The overall objective is to achieve a sustained agriculture growth rate of four to five percent per annum to support the overall GDP growth trajectory. ${ }^{b}$

The prime focus of the government is on high value agriculture including horticulture, livestock and fisheries. Concerted efforts are being made to improve farm level practices and developing linkages of farmers with markets and industry based on new technologies, ideas and future pathways for sustainable growth of agro industry.

$\mathrm{CPEC}=$ China-Pakistan Economic Corridor, GDP = gross domestic product.

Sources:

a Government of Pakistan, Ministry of Finance. Pakistan Economic Survey 2016-17. p. 19. http://www.finance.gov.pk/ survey_1617.html.

b Government of Pakistan, Ministry of Finance. Pakistan Economic Survey 2015-16. p. 23. http://www.finance.gov.pk/ survey_1516.html.

c Government of Pakistan, Ministry of Finance. Pakistan Economic Survey 2014-15. p. 23. http://www.finance.gov.pk/ survey_1415.html.

The more detailed and agriculture-specific documents, such as the Pakistan Vision 2025 and Punjab Growth Strategy 2018, recognize the current shortcomings of the R\&D setup. However, the remedies envisioned do not include a revamp of existing institutions. Instead, the focus remains on increasing their funding, with some programs leading to increasing cooperation and extension. None of this amounts to the revolutionary change needed for Pakistan's R\&D to compete with that of other countries. For crops where the main focus is domestic food security and internal demand, inefficiencies in R\&D can be tolerated. But when the main commodity is a major foreign exchange earner, then R\&D is directly competing with that of other countries. In this aspect, the prospects of Pakistan's rice appear paler than those of India and other countries. 
Current gaps can be highlighted by comparing Pakistan's R\&D data with those of other countries. Figure 3 shows the level and trend of agriculture R\&D spending in Pakistan and four comparator countries. Pakistan has the lowest spending in the group, and the is the only one showing a decrease of funding for agriculture R\&D. ${ }^{9}$

\section{Figure 3: Agriculture R\&D Spending as a Share of Agriculture GDP, 2000-2012 (\%)}

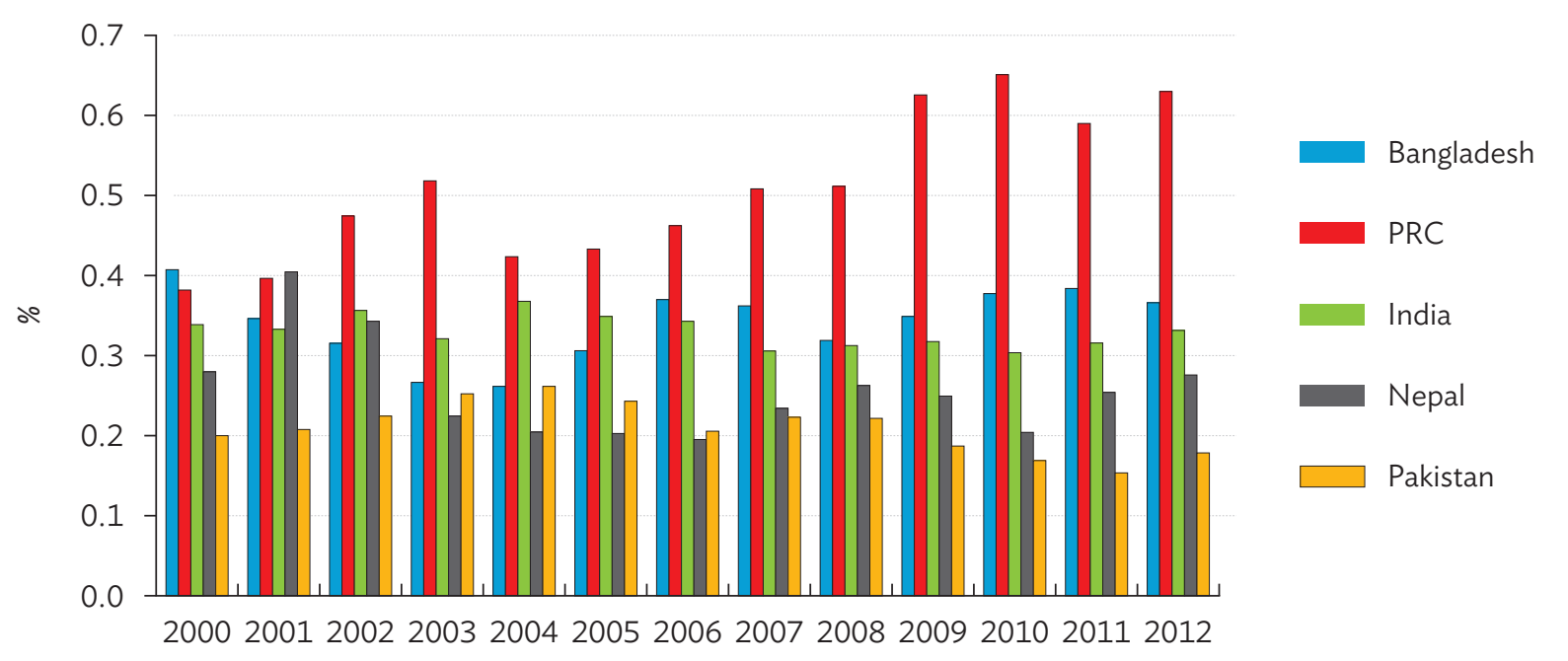

GDP = gross domestic product, PRC = People's Republic of China, R\&D = research and development.

Source: International Food Policy Research Institute (IFPRI). 2015. Agricultural R\&D Indicators Factsheet for Pakistan. Agricultural Science and Technology Indicators. Washington, DC.

A healthy level of R\&D spending does not require a substantial share of agriculture GDP. Allocating and maintaining a few additional basis points to agriculture's long-term growth could transform the sector. According to the Food and Agriculture Organization of the United Nations, a healthy and desirable target for developing countries is to allocate $1 \%$ of agriculture GDP to R\&D. ${ }^{10}$

While the level of overall spending can be one of the most important determinants of agricultural progress, the relevance of the spending to directly affected stakeholders in the value chain is equally important. Figure 4 highlights that Pakistan's R\&D expenditure per farmer has been on a downward trend, which is a very strong indicator of lack of strategic commitment and long-term planning, whereas such spending in the comparators is trending upward. ${ }^{11}$

9 Agriculture R\&D funding here includes all sources, internal and external.

10 Beintema, N. and H. Elliot. 2011. Setting Meaningful Investment Targets in Agricultural Research and Development. In P. Conforti (ed.) Looking Ahead in World Food and Agriculture: Perspectives to 2050. Rome: Food and Agriculture Organization of the United Nations.

$11 \quad$ While surveys try to quantify agriculture R\&D spending in terms of human and financial resources, an internationally accepted measure for comparison is research intensity, which specifies total public sector agriculture R\&D spending as a percentage of agricultural GDP. See Beintema, N. and G. Stads. 2008. Agricultural R\&D Capacity and Investments in the Asia-Pacific Region. Research Brief No. 11. Washington, DC: International Food Policy Research Institute. 
Figure 4: Total Agriculture R\&D Spending per 100,000 Farmers, 2000-2012 (2011 PPP, \$ million)

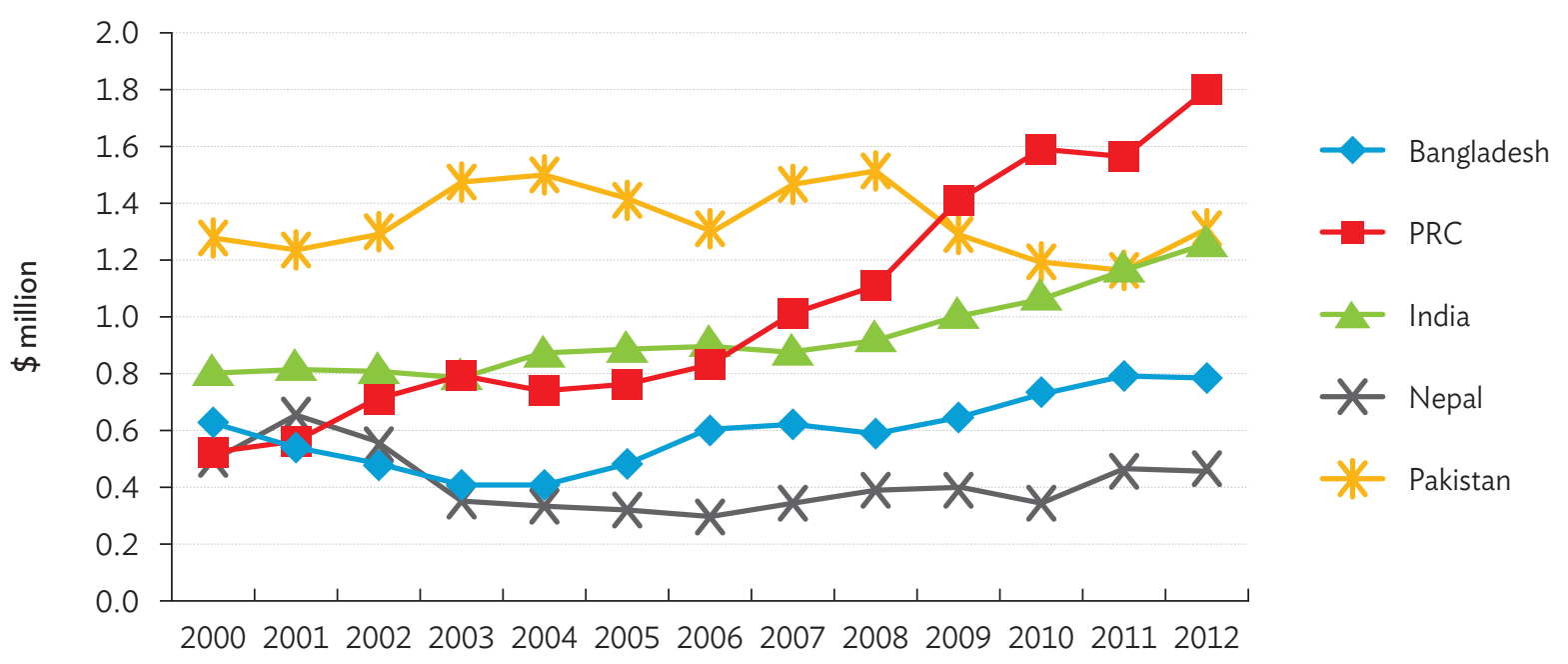

PPP = purchasing power parity, PRC = People's Republic of China, R\&D = research and development.

Note: Latest data.

Source: International Food Policy Research Institute (IFPRI). 2015. Agricultural R\&D Indicators Factsheet for Pakistan. Agricultural Science and Technology Indicators. Washington, DC.

The quality of Pakistan's research scores poorly in terms of spending per farmer and in the number of researchers possessing PhDs (see Footnote 8). However, Figure 5 shows the number of full-time agriculture researchers per farmer is very high.

Although the number of researchers per farmer is high, in part because the average farm holding in Pakistan is relatively larger than that in other countries, the number of highly qualified researchers is low, due to the low level of investment in agriculture researchers. The result is poor R\&D output. The career, remuneration, and incentive structure for agriculture researchers does not create an environment that can foster innovation. Agriculture researchers commonly retire on the same pay scale in which they started their careers. In the absence of a career enhancement structure, an average researcher has no incentive to perform well. The extremely low pay scale for hiring and keeping research staff leads to a higher head count of low-quality human resources, as many of the more ambitious and capable researchers will move on to other employment. Thus, R\&D resources are spread too thinly.

Another factor highlighted in the IFPRI study is the low share of PhDs in the sector compared with India. Further, most of the current researchers who have $\mathrm{PhDs}$ are in the second half of their careers, and the pipeline for replacing them when they retire is too constricted to fill the need for better and more research going forward. So, while the number of researchers per farmer is high, the number of highly qualified researchers is low. 


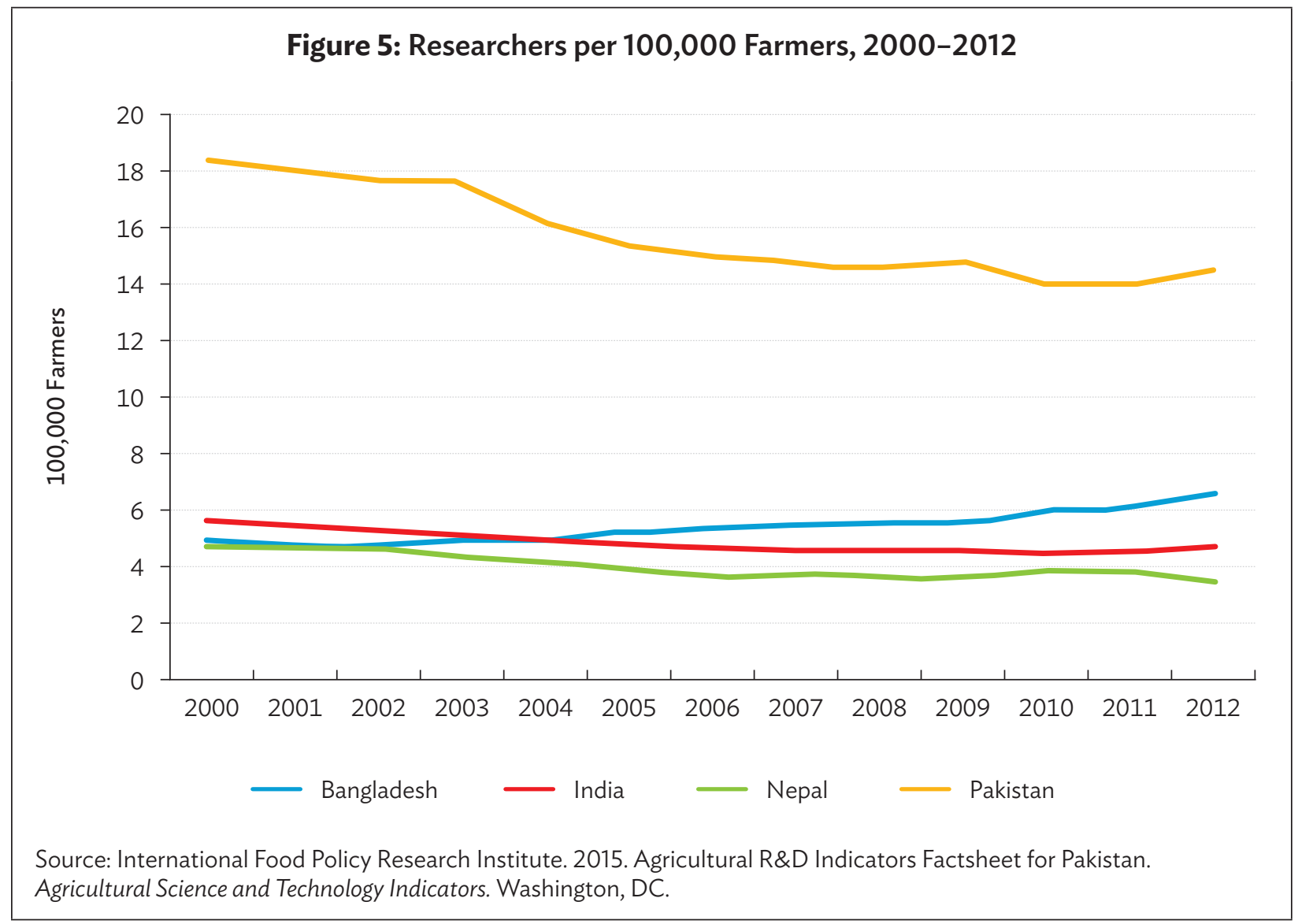

Models from other countries, including India, ${ }^{12}$ have reward and incentive structures for agriculture research that extract high value. Pakistan's current structure for public sector employees makes it almost impossible to bring reform without a major change. Applying reform measures only to new intakes would delay reaping benefits for a generation. A strong long-term policy and financial commitment are needed for an overhaul of the current R\&D system, which is unable to meet the current and future challenges faced by agriculture in general and rice in particular.

The continuing reliance on government institutions for $R \& D$ has two regressive impacts. First, the public sector's efficacy in leading innovation is very poor. Second, the government discourages the private sector and universities from leading research, which results in the country missing out on the contribution from a considerable pool of intellectual resources. In contrast, India has a healthy balance

12 A strategic initiative taken at Indian Council of Agricultural Research in 1990 was the establishment of a basmati research network with the specific goal of improving basmati rice for increased productivity and export purposes. With long-term funding commitment from a cess fund and coordination across different research institutes, over a 20-year period the country was able to develop higher-yielding, shorter-duration, and disease-resistant varieties. The almost doubling of yields from this strategic plan is a testament to the benefits of consistent and focused resource allocation. Rani, N. 2009. Present Status of Basmati Research in India. Hyderabad: Directorate of Rice Research. 
between universities and government facilities (Figure 6). This balance has been kept constant for more than 10 years, providing evidence of long-term policy. Pakistan's educational institutions have a much smaller role in agriculture R\&D than is the case in India. While this balance has been slowly improving in the last 10 years, it is a result of growth of the higher education sector rather than a result of policy designed to align agriculture R\&D.

\section{Figure 6: Share of Agriculture R\&D, Government and Higher Education Institutions, India and Pakistan (\% of total)}

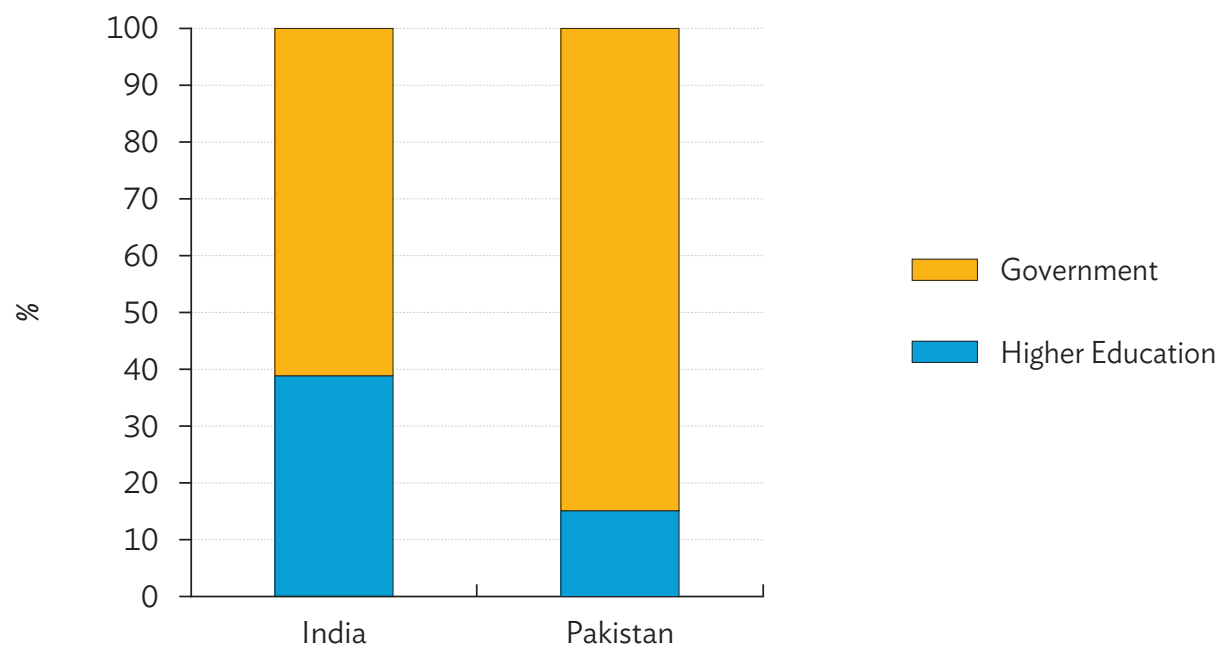

Source: International Food Policy Research Institute. 2015. Agricultural R\&D Indicators Factsheet for Pakistan. Agricultural Science and Technology Indicators. Washington, DC.

With modern emphasis on viewing the whole agriculture value chain as one unit, the fragmentation of R\&D makes it even more difficult to achieve the objective of coordinated and focused research. Countries such as Malaysia have made tremendous progress in streamlining R\&D with the result that commercialization of R\&D is taken as part of the R\&D effort." This approach is termed "research, development, and commercialization." An end-to-end approach of looking at a whole sector results in improved efficiencies throughout the value chain.

13 Government of Malaysia, Ministry of Science, Technology and Innovation. 2015. Research, Development and Commercialisation (R,D\&C). Science Outlook 2015. Kuala Lumpur. 


\section{BASMATI RICE RESEARCH AND DEVELOPMENT}

Underinvestment in basmati R\&D has led to underperformance of the subsector. The structure of public sector R\&D is such that merely increasing budgetary allocations will not achieve the intended purpose. A wholesale reform of the public sector R\&D institutional structure is almost impossible given incumbent interests and the absence of political motivation. As it may be easier to reform the approach to one crop than to the entire system, focusing on that crop may be the short-term answer.

Lack of funding for primary R\&D creates issues for the whole value chain of any commodity. Many factors affect the competitiveness of Pakistan's rice trade in international markets, but the primary hypothesis that is the lack of funding for research on basmati over the years has directly contributed to its diminishing share of rice production and export potential by not preparing the subsector to adequately face changing market dynamics and other environmental challenges.

While investment in basmati $R \& D$ requires attention to the entire value chain, the single most important aspect is to develop seed varieties that can thrive in changing ecological and marketing environments. Incremental contribution of improvements in sowing, transplanting, irrigating, weeding, pest control, fertilizer use, harvesting, drying, transport, storage, processing, export, and regulation could add considerably to the overall strength of the sector. However, all these steps are influenced to a great extent by the type and quality of seeds.

Domestic research institutions have developed a broad portfolio of basmati varieties catering to various environmental conditions. However, the excellent performance of these varieties that is reported from research sites and laboratories is not replicated at the farm level. Often there is insufficient seed of the new varieties for farmer trials. In individual interviews with the authors, rice researchers laid the blame on the lack of uptake on farming practices. An issue is the perception that the role of research stops at the door of the laboratory or research farm. This disconnect needs to be resolved by policy makers before significant advances can be made in research outcomes.

While macro-level data on basmati production and export are available, analysis requires detailed data on R\&D spending. In the absence of a single entity overseeing the entire R\&D for basmati, information is spread among various institutions. Multiple entities, often with overlapping efforts, have been conducting research on basmati, including (i) PARC; (ii) AARI; (iii) RRI; (iv) Nuclear Institute for Agriculture and Biology; (v) National Institute for Biotechnology and Genetic Engineering; (vi) University of Agriculture, Faisalabad; and (vii) PARB. In addition, the Rice Research Institute at Dokri in Sindh has twice the budget of the RRI at Kala Shah Kaku, but the former is focused on nonbasmati varieties. While the foregoing sources do not provide all the basmati research, they do constitute the bulk of public sector R\&D expenditure on basmati. As a proxy, data and previous research on total agriculture R\&D spending can also be used to fill gaps in basmati or rice-specific data. 
According to the latest data from Ministry of Finance and State Bank of Pakistan, rice accounts for 3.0\% of agriculture's value addition, ${ }^{14}$ contributes $0.6 \%$ to overall GDP (see Footnote 14 ), and contributes $9 \% 15$ of the country's foreign exchange export earnings. The share of full-time agriculture researchers in the total full-time public sector research workforce is also 9\%. Given that the number of full-time researchers has very little bearing on the quality and quantity of R\&D value addition, a better proxy is actual funding and its output.

The starting point for R\&D funding analysis is PARC, Pakistan's primary agriculture R\&D agency. It has a wide mandate to coordinate research among federal, provincial, and higher education institutions. An important component of PARC funding for R\&D is disbursements for competitive grants from an endowment fund, the Agricultural Research Endowment Fund (AREF). The AREF is a major source of domestic funding for agriculture research. Since 2002, the AREF has provided financial resources for 410 projects amounting to PRs1.7 billion (approximately $\$ 20$ million) across all areas under its mandate, including animal sciences, crop sciences, natural resources, and social sciences. Of the 410 projects, only 18 relate to the rice sector, and only 2 explicitly focus on basmati.

Similar to the overall agriculture research setup, research on basmati is fragmented among numerous agencies at the federal and Punjab levels. Although PARC was established to lead and coordinate agriculture research in the country, the 18th amendment resulted in agriculture being devolved to the provinces. However, PARC still plays an important role in channeling AREF R\&D funding through PARC's Agricultural Linkages Program. The second most important driver of research in basmati is the PARB. Most other research on basmati conducted in the public sector is done at the RRI, Kala Shah Kaku; the National Institute for Biotechnology and Genetic Engineering, Faisalabad; and the Nuclear Institute for Agriculture and Biology, Faisalabad. Table 2 gives the R\&D expenditure of the five institutes.

Table 2: Expenditure on Rice Research at Government Institutes

\begin{tabular}{lccc}
\hline Institute & $\begin{array}{c}\text { PRs } \\
\text { (million) }\end{array}$ & $\begin{array}{c}\text { Approximate \$ Equivalent } \\
\text { (million) }\end{array}$ & Number of Years \\
\hline NIAB & 74.9 & 0.6 & 20 \\
\hline NIBGE & 33.5 & 0.3 & 12 \\
\hline PARB & 110.6 & 0.9 & 5 \\
\hline PARC & 50.8 & 0.4 & 20 \\
\hline RRI & 533.9 & 4.3 & \\
\hline Total & 803.7 & 6.4 & \\
\hline
\end{tabular}

NIAB = Nuclear Institute for Agriculture and Biology, NIBGE = National Institute for Biotechnology and Genetic Engineering, PARB = Punjab Agricultural Research Board, PARC = Pakistan Agricultural Research Council, RRI = Rice Research Institute.

Source: Data obtained by the author from the NIAB, NIBGE, PARB, PARC, and RRI.

14 Government of Pakistan, Ministry of Finance. 2017. Pakistan Economic Survey 2016-2017. Islamabad.

15 State Bank of Pakistan. Export by Commodity. www.sbp.org.pk/ecodata/Export_Receipts_by_Commodity.xls (accessed 21 October 2018). 
Over the years, the four foregoing institutes have done the bulk of research on basmati, and collectively cover almost all public sector R\&D on the crop. The RRI is the country's oldest such institute and has some significant achievements to its credit. Its current organizational structure and operational setup was suitable when designed in 1970, but it has now fallen behind modern requirements for demandbased R\&D. In addition to the drawback of government policies regarding compensation and incentives, the RRI suffers from an absence of a dedicated research budget, which is a major drawback to innovation, speed of adaptability to commercial imperatives, and consistency of development. Public sector research institutes need initial capital investment to provide the requisite physical infrastructure, but then need sufficient annual budgets for salaries, allowances, and running costs of facilities. This basic funding model is not conducive to providing researchers with the opportunity for a healthy career growth; thus, even existing resources are not able to motivate personnel to excel in their work.

Comparing government expenditure on rice research at public institutions in Punjab shows that it is not proportional to the size and importance of the crop. Of the RRl's total annual budget, more than $80 \%$ is spent on salaries and expenses, and the rest is the minimum required for upkeep of the facilities. The research budget is too low for the kind of research output needed. Under such conditions, it cannot be expected that one of the largest exporters of rice in the world could remain competitive and innovative consistently year after year.

The setup and expenses of the rice research team at the Nuclear Institute for Agriculture and Biology are similar to those at the RRI. Both institutes have developed many new rice varieties, but they have not been adopted by farmers, so that for practical purposes such efforts are not benefiting the subsector. The two reasons are that the R\&D mandate of these institutes is considered limited to laboratory demonstrations, and the R\&D efforts are not aligned with the market's needs. However, the 2015 agriculture growth strategy of the Punjab mentions increasing the ratio of operating budgets compared to salary budgets, and an increased focus on commercialization of R\&D at the university level. ${ }^{16}$

All basmati-specific research projects undertaken at the institutes have been funded by grants through PARC and PARB. These, in turn, have been financed by the government's annual development plans, external financing assistance, and endowment funds. The combined result remains that the efforts are not streamlined and focused. The overall impact of basmati research is fragmented and haphazard, resulting from the lack of an overall strategy to coordinate and lead innovation.

\section{CONSEQUENCES OF LIMITED RESEARCH AND DEVELOPMENT BUDGET FOR BASMATI RICE}

The effects of the low level of R\&D investment are manifested in multiple ways. Given the time lag between R\&D and marketing of the result, several years may elapse before the impact is realized. Since the consequences of R\&D spending are long term, any attempt at increasing and rationalizing it will also take time to bear fruit. Figure 7 compares trends in exports of basmati and all types of rice. Clearly, in these measures, Pakistan's basmati has been declining since 2009-2011 compared with the other varieties.

16 Government of Punjab, Agriculture Department. 2015. Punjab Agriculture Sector Plan 2015. Lahore. 


\section{Figure 7: Export Volume and Value of Pakistan's Basmati and Nonbasmati Rice, 2001-2015}
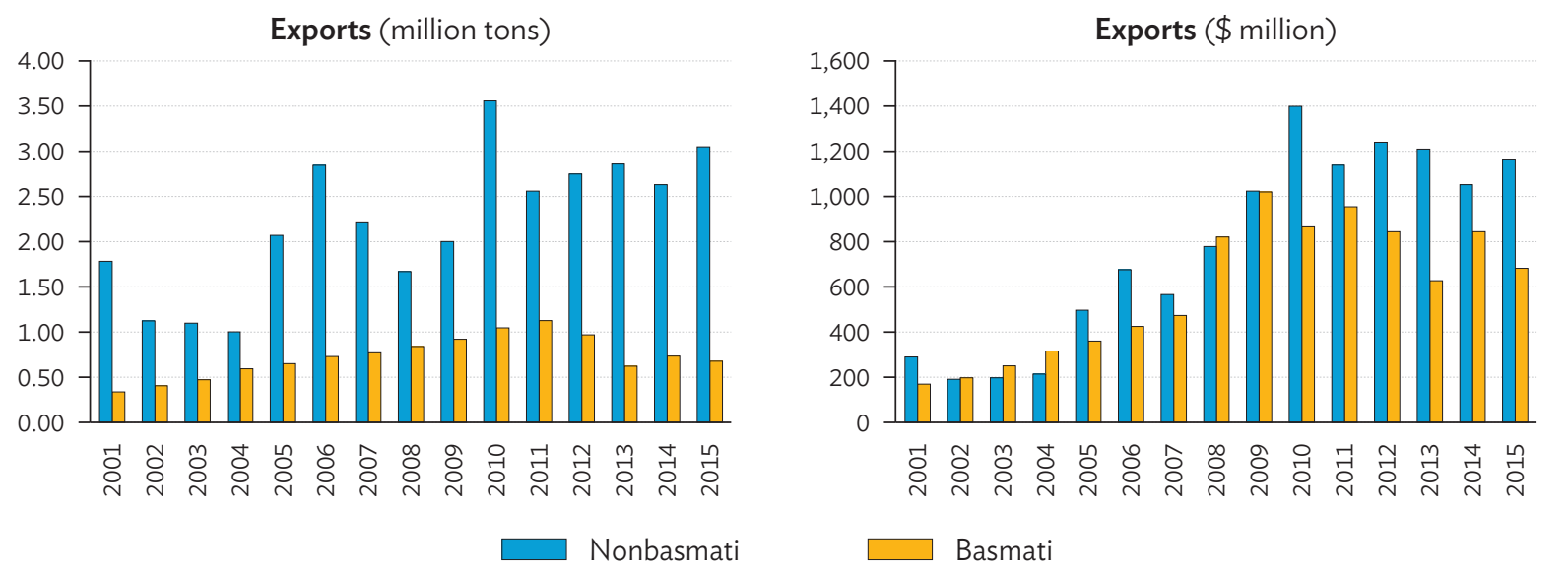

Source: Rice Exporters Association of Pakistan. www.reap.com.pk (accessed 22 June 2017).

After reaching a peak export level in 2011, basmati's export value has been decreasing. Five main reasons for the decline, based on stakeholder interviews, are (i) bacterial leaf blight, (ii) rejection of export shipments due to the presence of aflatoxins resulting from harvesting of wet paddy, (iii) fraudulent trade practices of mixing nonbasmati varieties in basmati shipments, (iv) encroachment of high-yielding nonbasmati varieties into traditional basmati cultivation areas, and ( $v$ ) closure of the Iran market due to United Nations sanctions.

During 2010-2015, each of these factors has affected basmati exports at different times. Some years have been impacted by bacterial leaf blight, other years by trade practices and market conditions. Competition from nonbasmati varieties is a continuing trend over the years. A common thread that runs through all the factors is the absence of a foresight mechanism to prepare the sector for the disruptions. A sound R\&D institutional setup is the foundation that can help the whole value chain cope with changing circumstances.

Combating bacterial leaf blight requires a consistent and long-term commitment. Most efforts have been short-term projects as opposed to secure long-term funding. The continuing practice of harvesting and bringing wet paddy to market is also an R\&D failure. The result is not only lost revenue but also damage to the image and reputation of the country's rice, which takes time to rebuild. Progress is needed in designing practical on-farm drying solutions to avoid contamination later in the value chain.

Combating the competition from high-yielding nonbasmati varieties should be a strategic priority for basmati to be recognized as a unique variety that deserves special attention. While market forces are often the determinants of which variety gets greater acceptance, better R\&D investment improves a variety's chances of securing market attention. Basmati needs a higher level of resource allocation to compete equally with nonaromatic high-value varieties. Even when research produces good basmati varieties, the failure to adequately connect them to production results in little benefit accruing to the basmati subsector. 
Imported nonbasmati varieties of nonaromatic, long-grain, high-yielding rice are attracting prices similar to that of basmati, and are increasing their share of production (Figure 8). These varieties will continue to infringe on traditional basmati territory. Their encroachment and future threat is clear evidence of the failure of basmati R\&D. The preparation of adequate responses to the impact of economic factors is an integral function of modern, commercially responsive R\&D systems. Changes in input and labor costs also affect farmers' behavior and can cause them to shift to other varieties.

Figure 8: International Price of Pakistan’s Basmati and Nonbasmati Coarse Rice, 2001-2015 (\$/ton)

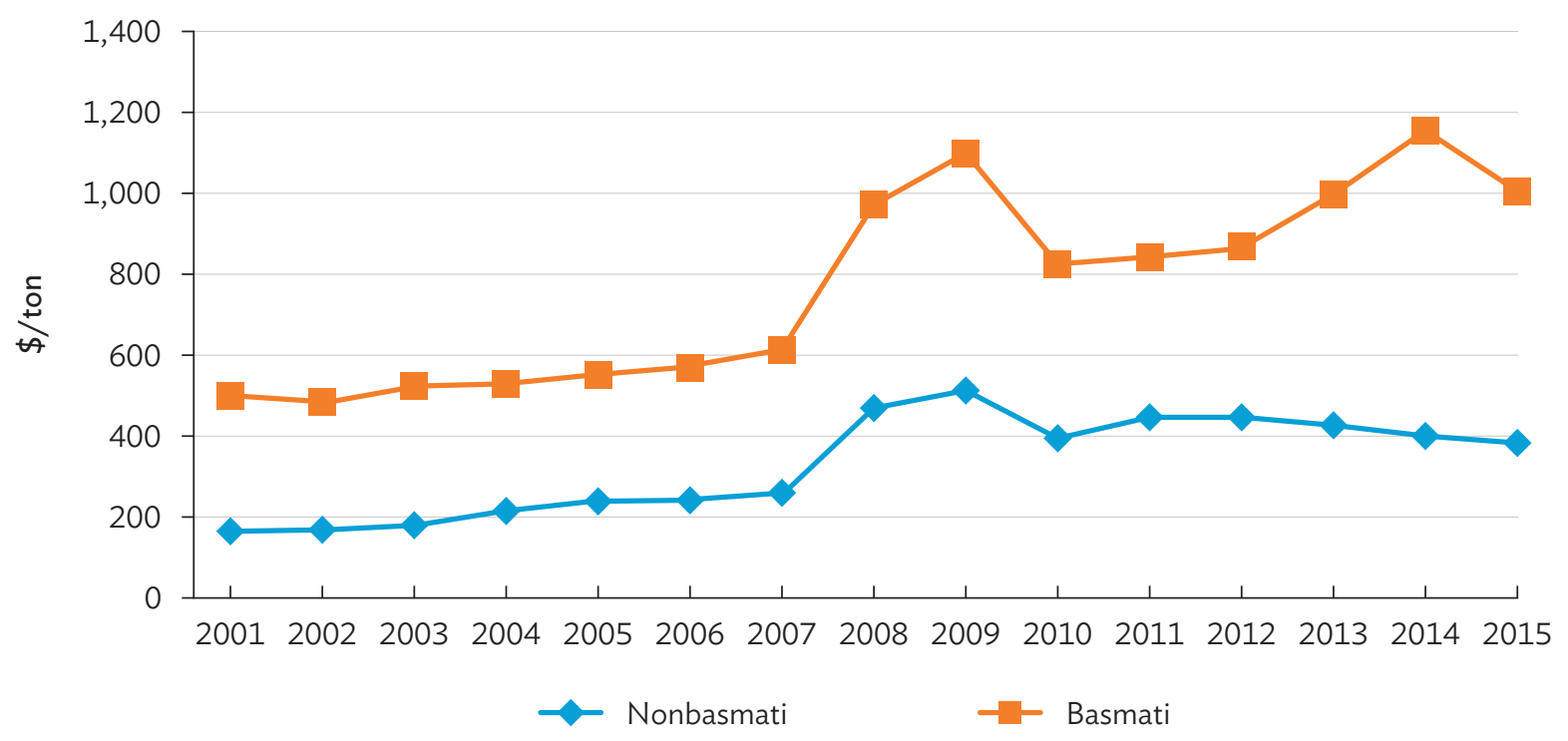

Source: Rice Exporters Association of Pakistan. www.reap.com.pk (accessed 22 June 2017).

Given that basmati has the enviable status of being a unique, high-value variety that is grown only in a specific geographical location, and brings considerable export revenues to the country, it should have a special status in terms of priority and focus of investment. Numerous countries have allocated extra resources to commodities of choice that bring substantial export revenues, for example palm oil in Malaysia. In Pakistan, cotton has its own ministry at the federal level. Rice may not need a separate ministry, but at least it merits a basmati rice board with responsibility for basmati's whole value chain.

A comparison of domestic yields of average versus progressive farmers (Table 3) highlights the gap that can be filled by better R\&D. Given better access to resources, progressive farmers are able to generate higher yields. This demonstration is important in proving that higher yields are possible within the same environment. Closing this domestic gap should be a continuing goal of policy makers. A good R\&D institutional setup should be aiming for best international targets. 
Table 3: Rice Yield Gaps in Pakistan

\begin{tabular}{lcccc}
\hline & $\begin{array}{c}\text { Yield } \\
\text { (tons/hectare) }\end{array}$ & Yield Gap & Gap & Gap Description \\
\hline $\begin{array}{l}\text { World's Highest } \\
\text { Yield (US) }\end{array}$ & 7.4 & 4.5 & $61 \%$ & $\begin{array}{c}\text { Gap = World highest - Pakistan national } \\
\text { average }\end{array}$ \\
\hline $\begin{array}{l}\text { Potential Yield } \\
\begin{array}{l}\text { Progressive } \\
\text { Farmer Yield }\end{array}\end{array}$ & 5.2 & 0.6 & $12 \%$ & $\begin{array}{c}\text { Research gap = Potential yield - Progressive } \\
\text { farmer yield }\end{array}$ \\
\hline National Average & 4.6 & 1.7 & $37 \%$ & $\begin{array}{c}\text { Extension gap = Progressive farmer yield - } \\
\text { National average }\end{array}$ \\
\hline
\end{tabular}

US = United States.

Source: Aslam, M. 2016. Agricultural Productivity Current Scenario, Constraints and Future Prospects in Pakistan. Sarhad Journal of Agriculture. 32(4): 289-303.

In the short term, large variations in yield from year to year do not reflect the stability of the subsector. The large dip in yield in 2012 due to blight and floods was recovered the following year. However, the cycle of dips and peaks shows that the subsector is at the mercy of factors that can be, but currently are not being, managed. Good R\&D could help preempt disruptions and provide resilience to potential shocks. Whether a change entails the onset of disease, new varieties, changes in environment, or technological advances, an efficient R\&D system would be proactive rather than only reactive to issues as they arise.

As a major international player in rice, Pakistan should also aim to be a leader in innovation through its R\&D efforts. However, the deficiency even in the use of basic planting, harvesting, and drying techniques clearly indicates that stakeholders have been left to their own devices. In Pakistan, where numerous assets have been classified as strategic for the country's needs, it is high time that basmati is granted the same status.

\section{EMPIRICAL ANALYSIS OF THE IMPACT OF RESEARCH AND DEVELOPMENT ON BASMATI EXPORTS}

To estimate the impact of R\&D investment on the volume and the value of basmati rice exports, a vector autoregression (VAR) model was fitted to the data for the period 1997-2014. ${ }^{17}$ The impact on both the volume and value of exports was evaluated. Each VAR equation includes three variables: (i) volume and value of exports, (ii) yield, and (iii) R\&D expenditure. Because R\&D expenditure is not available specifically for basmati rice, the annual budget for the RRI is used as a proxy. Table 4 summarizes the statistics for these variables and Figure 9 shows the behavior of the log of each variable over time.

$17 \quad$ Data are not available for earlier years. 
Table 4: Summary Statistics for the Vector Autoregression Indicators

\begin{tabular}{lccrrrr}
\hline Variable & Description & N & Mean & Std Dev & Min & \multicolumn{1}{c}{ Max } \\
\hline rri & R\&D investment & 18 & 23.30 & 15.0 & 8.2 & 56.2 \\
\hline yield & Yield $(\mathrm{kg} / \mathrm{ha})$ & 18 & $1,643.40$ & 153.2 & $1,302.0$ & $1,801.0$ \\
\hline xvol & Volume of exports & 18 & 687.10 & 214.5 & 341.5 & $1,119.6$ \\
\hline xval & Value of exports & 18 & $41,104.44$ & $28,807.5$ & $10,385.1$ & $81,758.3$ \\
\hline
\end{tabular}

ha = hectare; kg = kilogram; Max = maximum; Min = minimum; $N$ = number of observations; R\&D = research and development; rri = the annual budget of the Rice Research Institute, Kala Shah Kaku, Pakistan; Std Dev = standard deviation; $x v a l=$ export value of Basmati rice xvol = export volume of Basmati rice; $y$ yield $=$ Basmati rice yield .

Sources: R\&D data are from the Rice Research Institute; yield data are from the Pakistan Bureau of Statistics, various years (accessed 5 April 2017); export data are from the Rice Exporters Association of Pakistan, http://reap.com.pk/download/ index.asp (accessed 5 April 2017).

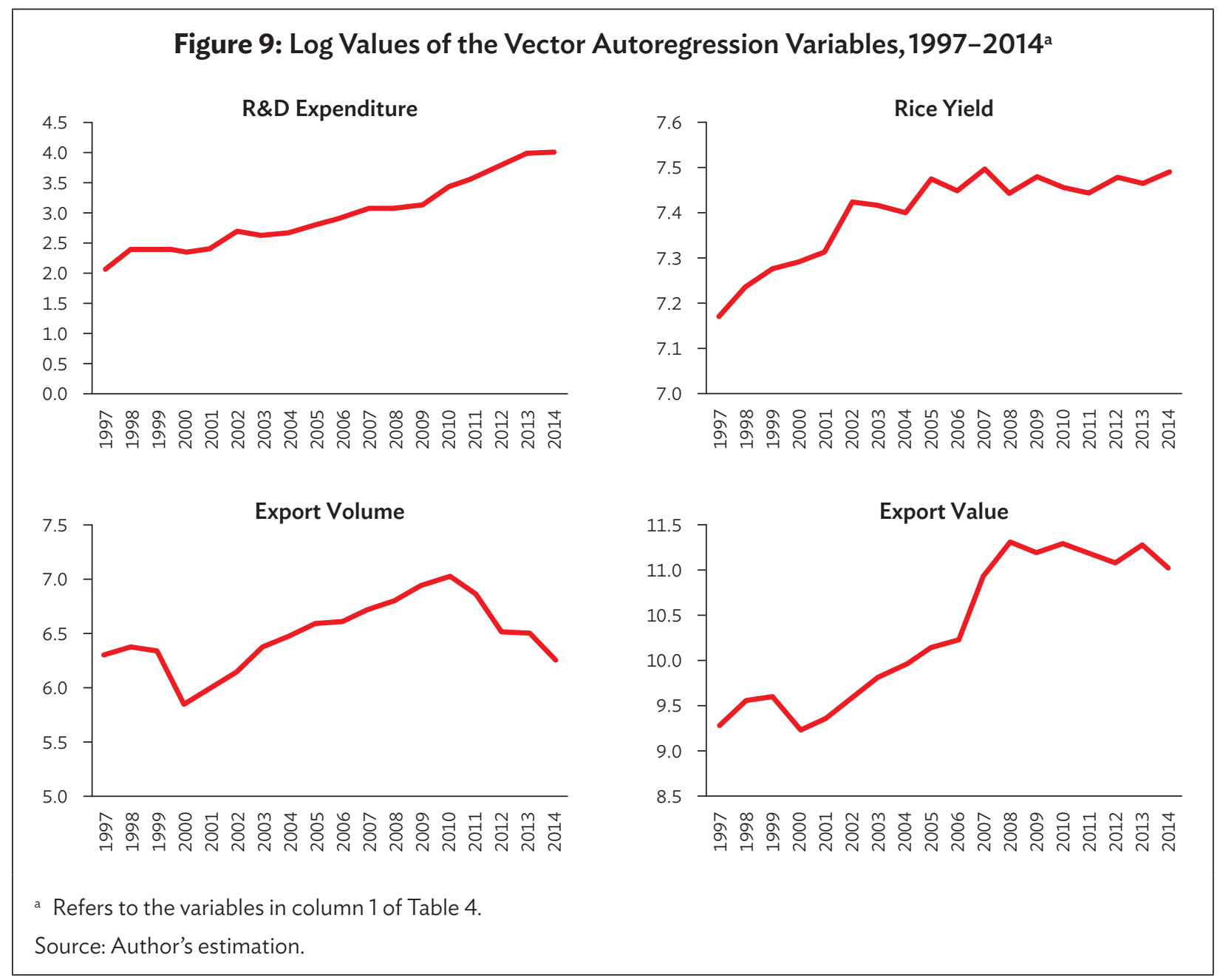


Figure 9 suggests nonstationarity in the data series. Thus, first differences were taken for each of the log-transformed values of the variables to make them stationary before constructing the VAR model. Dickey-Fuller tests for the unit root in the differenced time series are shown in Table 5. The null hypothesis of a unit root is rejected at the $5 \%$ level of significance for all series indicating that the first differences of the log of each variable are stationary.

Table 5: Dickey-Fuller Tests for a Unit Root

\begin{tabular}{lcccccc}
\hline & & & & \multicolumn{3}{c}{ Interpolated Dickey-Fuller } \\
\cline { 6 - 7 } Variable & $\begin{array}{c}\text { Observations } \\
(\#)\end{array}$ & $\begin{array}{c}\text { Test Statistic } \\
\mathbf{Z}(\mathrm{t})\end{array}$ & $\begin{array}{c}\mathrm{p} \text {-value for } \\
\mathbf{Z}(\mathrm{t})\end{array}$ & $\begin{array}{c}\text { 1\% Critical } \\
\text { Value }\end{array}$ & $\begin{array}{c}5 \% \text { Critical } \\
\text { Value }\end{array}$ & $\begin{array}{c}\text { 10\% Critical } \\
\text { Value }\end{array}$ \\
\hline $\mathrm{dLXVOL}$ & 16 & -2.933 & 0.0416 & -3.75 & -3 & -2.63 \\
\hline $\mathrm{dLXVAL}$ & 16 & -3.004 & 0.0345 & -3.75 & -3 & -2.63 \\
\hline $\mathrm{dLYIELD}$ & 16 & -5.516 & 0.0000 & -3.75 & -3 & -2.63 \\
\hline $\mathrm{dLRRI}$ & 16 & -4.623 & 0.0001 & -3.75 & -3 & -2.63 \\
\hline
\end{tabular}

$d L R R I=$ first difference in log of the annual budget of the Rice Research Institute, Kala Shah Kaku, Pakistan; $d L X V A L=$ first difference in log of export value of basmati rice; $d L X V O L$ = first difference in log of export volume of basmati rice; $d L Y I E L D=$ first difference in log of basmati rice yield.

Note: MacKinnon approximate $p$-values were calculated for the $p$-values of test statistic $Z(t)$.

Source: Authors.

Two sets of VAR models were fitted, one which includes the volume of exports and the other which includes the value of exports. Each VAR model has two lag lengths. ${ }^{18}$ The VAR model including the volume of exports is given by:

$$
\left[\begin{array}{c}
d L X V O L_{t} \\
d L Y I E L D_{t} \\
d L R R I_{t}
\end{array}\right]=a_{0}+b_{1}\left[\begin{array}{c}
d L X V O L_{t-1} \\
d L Y I E L D_{t-1} \\
d L R R I_{t-1}
\end{array}\right]+b_{2}\left[\begin{array}{c}
d L X V O L_{t-2} \\
d L Y I E L D_{t-2} \\
d L R R I_{t-2}
\end{array}\right]+\left[\begin{array}{c}
\varepsilon_{1 t} \\
\varepsilon_{2 t} \\
\varepsilon_{3 t}
\end{array}\right]
$$

where: $d L X V O L_{t}$ is first difference of log of export volume of basmati rice at time $t$, $d L Y I E L D_{t}$ is first difference in log of basmati rice yield at time $t$, $d L R R I_{t}$ is first difference in log of RRI's annual budget at time $t$, $e_{t}$ is an error term, $a_{0}$ is a vector of intercepts, and $B_{1}$ and $B_{2}$ are $3 \times 3$ matrixes of coefficients.

The same model holds for the VAR including of the value of exports, $d L X V A L$.

18 The varsoc command in Stata is a tool that recommends the number of lag lengths to include in the VAR based on several information criteria such as the Akaike Information Criterion and the Schwarz's Bayesian Information Criterion. For both VAR models, the number of lag lengths specified in the varsoc command was limited to a maximum of 4 lags since there were only 18 data points for analysis and adding more lags implies smaller degrees of freedom. For the XVOL series, varsoc recommends including 1 or 3 lags, and 3 lags for the XVAL series. 
A VAR model was initially fitted to the data. However, a meaningful model was not obtained for both volume and value of exports, i.e., the coefficient for $d L R R I$ was either not significant or significant but took on a wrong sign in the model and a 1 standard deviation shock to $d L R R I$ sent a negative impact to the volume/value of exports in the impulse response function. ${ }^{19}$ Given the ambiguousness of the VAR model and taking into consideration that R\&D expenditure can be perceived as an exogenous variable, the VAR-X model ${ }^{20}$ was fitted to the data alternatively to determine impact. The VAR-X model for $X V O L$ is given by:

$$
y_{t}=a_{\circ}+\sum_{i=1}^{p} B_{i} y_{t-1} \sum_{j=0}^{q} C_{i} x_{t-j}+e_{t}, y_{t}=\left[\begin{array}{l}
\text { DLXVOL } \\
\text { DLYIELD } \\
\text { DLi }
\end{array}\right], B_{i}=\left[\begin{array}{ll}
b_{11, i} & b_{12, i} \\
b_{21, i} & b_{22, i}
\end{array}\right], x_{t-j}=D L R R I_{t-j}
$$

Results for the VAR-X model are shown in Table 6. For $d L X V A L$, the coefficient of $d L R R I$ is significant and positive, indicating that there is a direct and positive relationship between R\&D expenditure and value of exports i.e., increasing R\&D expenditure significantly raises the value of exports. The impulse response functions in Figure 10 illustrate the impact of a 1 standard deviation shock on dLRRI to dLXVAL across an 8-year time horizon. The one-off shock on $d L R R I$ gave an instantaneous upsurge in $d L X V A L$ and its impact drifted through time.

Table 6: VAR-X Model for Export Volume and Value

\begin{tabular}{|c|c|c|c|c|c|c|c|}
\hline & & Coefficient & SE & & & Coefficient & SE \\
\hline \multirow{5}{*}{ dlxvol } & dlxvol.L1 & 0.2329 & 0.2962 & \multirow{5}{*}{ dlxval } & dlxval.L1 & 0.4727 & 0.3210 \\
\hline & dlyield.L1 & 1.2623 & 1.5088 & & dlyield.L1 & 2.1436 & 1.7478 \\
\hline & dlrri & 0.4730 & 0.5701 & & dlrri & $1.3844^{*}$ & 0.7337 \\
\hline & dlrri.L1 & -0.4149 & 0.5200 & & dlrri.L1 & -0.4352 & 0.6165 \\
\hline & _cons & -0.0317 & 0.1042 & & _cons & -0.0945 & 0.1323 \\
\hline \multirow{5}{*}{ dlyield } & dlxvol.L1 & 0.0107 & 0.0585 & \multirow{5}{*}{ dlyield } & dlxval.L1 & -0.0259 & 0.0553 \\
\hline & dlyield.L1 & -0.2793 & 0.2981 & & dlyield.L1 & -0.3051 & 0.3010 \\
\hline & dlrri & 0.0476 & 0.1126 & & dlrri & 0.0172 & 0.1264 \\
\hline & dlrri.L1 & -0.0176 & 0.1027 & & dlrri.L1 & -0.0007 & 0.1062 \\
\hline & _cons & 0.0182 & 0.0206 & & _cons & 0.0231 & 0.0228 \\
\hline
\end{tabular}

* = significant at the 10\% level; _cons = constant; $\mathrm{dLRRI}=$ first difference in log of the annual budget of the Rice Research Institute's annual budget; $d L X V A L$ = first difference in log of export value of basmati rice; $d L X V O L=$ first difference of log of export volume of basmati rice; dLYIELD = first difference in log of basmati rice yield; L1 = lag 1 year; L2 = lag 2 years; $\mathrm{SE}=$ standard error.

Source: Authors' estimation.

\footnotetext{
19 Results are available on request.

20 Bierens, H. 2004. VARModels with Exogenous Variables. http://www.personal.psu.edu/hxb11/EasyRegTours/VAR_Tourfiles/ VARX.PDF.
} 


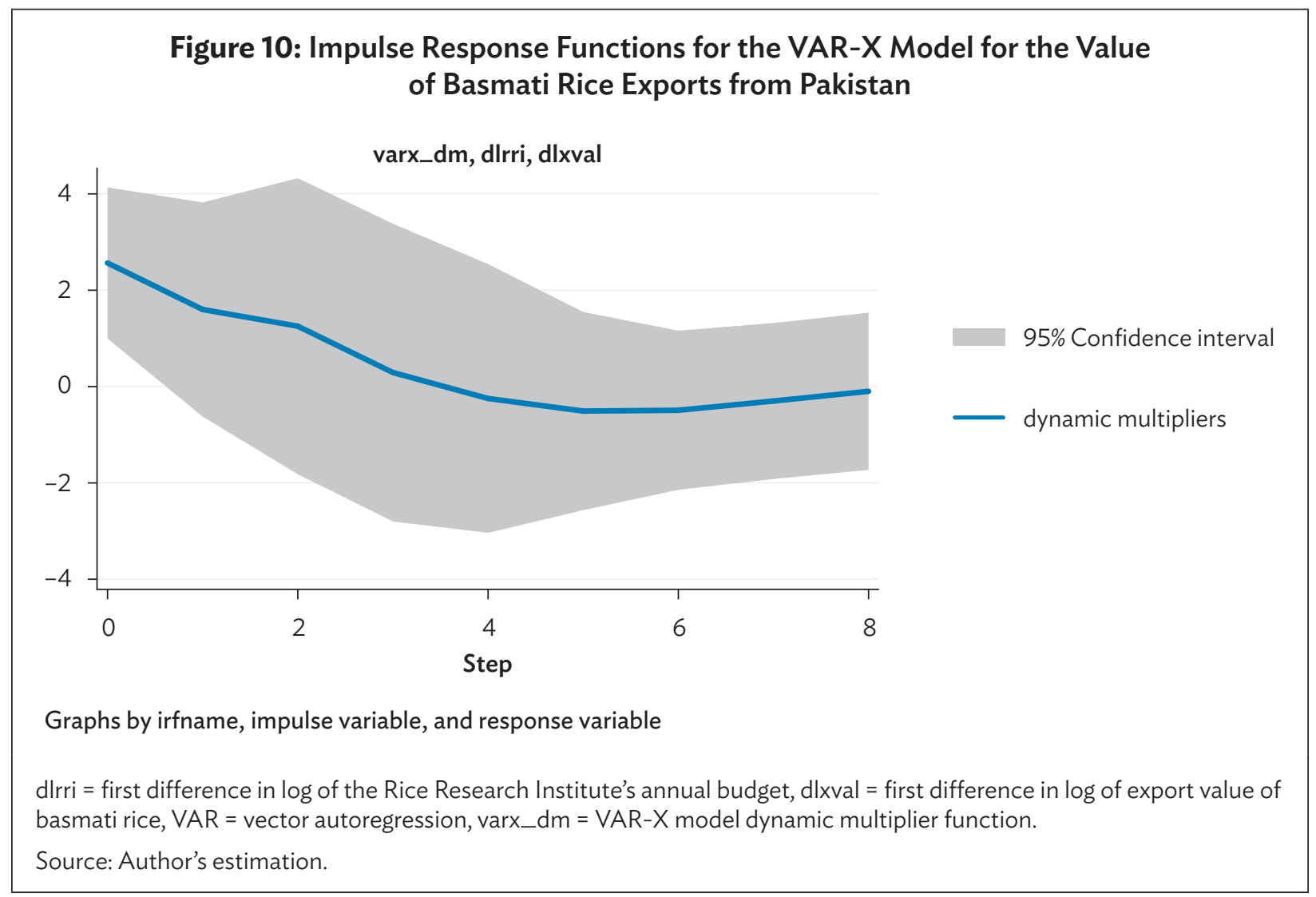

\section{CONCLUSION AND POLICY RECOMMENDATIONS}

Having established that the current funding levels for basmati R\&D are woefully inadequate and that Pakistan's basmati export could be increased by additional funding for basmati R\&D, the question arises as to the best remedy. Two important aspects need attention: first, the source of funding, and second, the oversight and transmission mechanism of the funding.

Modern models of R\&D funding rely on a combination of public grants, industry contributions, and fees and levies. However, a substantial increase from Pakistan's public exchequer is unlikely. One option is to institute a cess (levy) fund based on contributions from farmers. An expanded version could involve all participants of value chain, so that all participants' resources can be pooled for mutual benefit, given that rice R\&D is advantageous to all stakeholders in the value chain. However, the expectation that Pakistan's farmers will willingly agree to an R\&D levy is unrealistic, as their ability to pay is uncertain and they frequently complain about input costs and lack of subsidies.

Alternately, the other end of the chain might be more conducive to such an initiative. Processing and export stages involve the greatest value addition for rice. Such stages of the value chain are also better documented, better organized, and more cognizant of the need for better R\&D to be able to compete in 
international markets. The burden of a cess at the export end is less onerous than at the farm end, and the amount that can be collected will be greater. Given that the exporters gain the most in the rice value chain, it is only fair that R\&D contributions should come from them. And, imposing a levy at the farm end could distort the growers' behavior to the detriment of rice cultivation if they switch to other crops.

Furthermore, an additional levy on exporters would not be needed if the current levy is channeled as intended. In 1999, Parliament passed the Export Development Fund Act. Under the Act, all exporters, including rice exporters, pay a surcharge of $0.25 \%$, which is deducted by the exporter's bank from foreign receipts and submitted to the State Bank of Pakistan. The bank transfers the collected cess to the Ministry of Finance (MOF). Under the Act, the MOF must transfer all proceeds of the Export Development Fund to the Ministry of Commerce (MOC), which is responsible for disbursing the proceeds according to the stipulations of the Act.

In reality, the MOF has not been transferring all the amounts to the MOC. The MOC has, as a result, a large sum due from the MOF. The cess collected in 2017 from rice exporters is equal to half of all expenditure on rice R\&D for the last 20 years. The Act specifies that the cess funds can be used for R\&D, technical institutes, market and product development, and other areas related to export enhancement. Further, the Rice Exporters Association of Pakistan has, on many occasions, requested the release of funds for basmati development.

Thus, while the industry has contributed for many years to a cess fund designed exactly for improving the export product, the government apparatus has made the scheme ineffectual. ${ }^{21}$ While the Export Development Fund is administered by a ministry dealing with exports, the association of rice exporters is the conduit between agriculture and export. The common interests of rice exporters and growers can be channeled through the proper application of funds from this cess. However, competing interests have prevented this goal from being achieved.

As noted, the efforts of scientists and researchers do not translate into commercial success for various reasons, and exporters and processors note the lack of competitive edge due to insufficiencies in R\&D. While the export segment of the value chain benefits most from rice in terms of private profits, exporters still expect the public sector to fund core R\&D. The inability to view the whole value chain means that the billions of rupees that have been collected from rice exporters in the last 20 years have not been used for basic R\&D. The vision of the Export Development Fund or the exporters is not broad enough to realize that all R\&D across the value chain will contribute to increased export revenues. The current narrow focus on marketing and international roadshows exemplifies the misunderstanding about commercialization of R\&D.

21 While there are no official published data on the amount of the levy collected against rice exports, it can be estimated based on a rate of $0.25 \%$ and total rice exports of $\$ 25$ billion from $2000-2018$, which gives a figure of $\$ 65$ million. No amount from this export development contribution of rice exports has been made available to the sector. A fraction of this amount over the last 20 years would have been enough for the sector to face various challenges. See REAP. Rice Export Figures-2010 to 2018 and Country Wise Exports 2017-2018. http://reap.com.pk/admincp/download/Upload_ files/2010-18\%20Export\%20Figures.pdf (accessed 29 October 2018); and Rice Export Data, July 2000 to June 2014. http://reap.com.pk/admincp/download/Upload_files/Rice\%20Export\%20July\%202000\%20to\%20June\%202014.pdf (accessed 29 October 2018). 
The amount of funding required to revive growth in basmati production and export is not huge. Recent policy work, especially in Punjab, has recognized the need for investment in R\&D. ${ }^{22}$ Funds are available in the government's annual development budget. The ongoing ADB Punjab Basmati Rice Value Chain Technical Assistance Project has found a dearth of good project proposals and project management capabilities. The current project has highlighted the problem that scientists find it difficult to spend even small grant amounts within a project duration. Any effort to modernize and streamline agriculture R\&D must involve a holistic approach that includes the use of government development funds and the application of the Export Development Fund. Policy makers and treasury officials need to be convinced that the amount of R\&D funding required is small compared to the contribution made by the cess on rice exporters. The important point is to commit continuing funding every year for the whole value chain, which should be under the administration of a single entity.

Recent emphasis on public-private partnership (PPP) models of development offers a new avenue for changing the private sector's current rent-seeking approach and aligning it with the public sector policy revival. A PPP approach can considerably lower the funding burden on the public sector while at the same time creating an environment to align private sector goals with government policy. While implementing PPP interventions can be technically challenging, their potential benefits can be gained by resolving current bottlenecks.

The Malaysian Palm Oil Board (MPOB), a government body, is a good model of how the coordinated efforts of a whole value chain can improve the prospects of a particular crop. From plantations to processing to exports, the MPOB looks after the research, development, and commercialization of Malaysian palm oil (see Footnote 13). The MPOB has made Malaysian palm oil an international benchmark product and has invested heavily in R\&D and commercialization. The key feature of the MPOB model is that the MPOB oversees the whole value chain and research scientists are included in international marketing efforts as well.

Pakistan could create a basmati rice board (or an overall rice body for all varieties), based on the MPOB model, and funded by the rice exporters' contributions to the Export Development Fund. The board should have representation from all stakeholders and should be able to accomplish the goals of commercially viable R\&D for rice. Most of the components for such a model exist - the missing link is political will and policy decision-making.

As is the case for all R\&D in Pakistan's agriculture, basmati R\&D suffers from a low quality and quantity of funding. The core issue relates to an absence of policy commitment and the recognition of the need to invest a minimum amount consistently. The irony is that the amount of research investment needed is tiny compared with its potential return.

22 Government of Punjab. 2015. Punjab Growth Strategy 2018. Lahore. 
For the country's premier export product to be handled as an orphan is a tragedy. In the absence of R\&D-based preparedness, the subsector is exposed to multiple risks from internal as well as external sources. While overall revenues from rice are stable, the lack of growth of basmati revenues should be a red flag for policy makers. A reform program is urgently needed because years of underinvestment have weakened the system; however, some practical measures can reverse the trend.

The overriding requirement is for government to commit to a strategic road map that fills the R\&D gap. It should create an environment that enables the public and private sectors to engage in commercially viable research. The rice sector is already paying the bills for its development. The missing link is the utilization and channeling of the resources. New efforts may be needed to bypass the existing setup if it is too costly or rigid to reform. But, without a reform of R\&D, the future of the production and marketing of Pakistan's basmati rice is uncertain.

\section{REFERENCES}

Aslam, M. 2016. Agricultural Productivity Current Scenario, Constraints and Future Prospects in Pakistan. Sarhad Journal of Agriculture 32(4): 289-303.

Beintema, N. and H. Elliot. 2011. Setting Meaningful Investment Targets in Agricultural Research and Development. In P. Conforti (ed.) Looking Ahead in World Food and Agriculture: Perspectives to 2050. Rome: Food and Agriculture Organization of the United Nations.

Beintema, N. and G. Stads. 2008. Agricultural R\&D Capacity and Investments in the Asia-Pacific Region. Research Brief No, 11. Washington, DC: International Food Policy Research Institute.

Bierens, H. 2004. VAR Models with Exogenous Variables. http://www.personal.psu.edu/hxb11/ EasyRegTours/VAR_Tourfiles/VARX.PDF.

Cheema, B. 2018. Basmati Rice-A Fragrant Heritage of Punjab, Pakistan. Presentation given at International Rice Congress, Singapore, 15-17 October.

Food and Agriculture Organization of the United Nations. FAOSTAT. http://www.fao.org/faostat/ en/\#data/TP.

Government of Malaysia, Ministry of Science, Technology and Innovation. 2015. Research, Development and Commercialisation (R,D\&C). Science Outlook 2015. Kuala Lumpur.

Government of Pakistan, Ministry of Finance (MOF) of Pakistan. 2017. Pakistan Economic Survey 2016-2017. Islamabad.

—. Various Years. Pakistan Economic Survey. Islamabad. http://www.finance.gov.pk.

Government of Pakistan, Pakistan Bureau of Statistics (PBS). Various Years. Agriculture Statistics. http://www.pbs.gov.pk/content/agriculture-statistics.

Government of Pakistan, Planning Commission of Pakistan. 2014. Pakistan Vision 2025. Islamabad. 
Government of Punjab. 2015. Punjab Growth Strategy 2018. Lahore.

Government of Punjab, Agriculture Department. 2015. Punjab Agriculture Sector Plan 2015. Lahore.

International Food Policy Research Institute (IFPRI). 2015. Agricultural R\&D Indicators Factsheet for Pakistan. Agricultural Science and Technology Indicators. Washington, DC.

Rani, N. S. 2009. Present Status of Basmati Research in India. Directorate of Rice Research. Hyderabad.

Rice Exporters Association of Pakistan (REAP). http://reap.com.pk/download/index.asp.

Rice Export Data, July 2000 to June 2014. http://reap.com.pk/admincp/download/ Upload_files/Rice\%20Export\%20July\%202000\%20to\%20June\%202014.pdf (accessed 29 October 2018).

_. Rice Export Figures-2010 to 2018 \& Country Wise Exports 2017-2018. http://reap.com.pk/admincp/download/Upload_files/2010-18\%20Export\%20Figures.pdf (accessed 29 October 2018).

State Bank of Pakistan. 2016. Basmati Rice Value Chain in Pakistan. Karachi.

—. Export Receipts by Commodity. www.sbp.org.pk/ecodata/Export_Receipts_by_Commodity.xls (accessed 21 October 2018).

United States Department of Agriculture (USDA). Various Years. Rice Yearbook. https://www.ers.usda.gov/data-products/rice-yearbook (accessed 11 April 2017).

\section{Further Reading}

Abedullah, S. and K. Mushtaq. 2007. Analysis of Technical Efficiency of Rice Production in Punjab. Pakistan Economic and Social Review 45(2): 231-44.

Ahmed, S. and M. Gautam. 2013. Agriculture and Water Policy: Toward Sustainable Inclusive Growth. Washington, DC: World Bank.

Akhtar, W., M. Sharif, and N. Akmal. 2007. Analysis of Economic Efficiency and Competitiveness of the Rice Production Systems of Pakistan's Punjab. Lahore Journal of Economics 12(1): 141-53.

Akmal, N., W. Akhtar, H. Shah, M. Naizi, and S. Tariq. 2014. The Structure and Competitiveness of Pakistan's Basmati Rice Exports. Asian Journal of Agriculture and Rural Development (4)4.

Beintema, N. et al. 2007. Agricultural Research and Development in Pakistan: Policy, Investments, and Institutional Profile. Washington, DC: International Food Policy Research Institute.

Hazell, P. 2008. An Assessment of the Impact of Agricultural Research in South Asia since the Green Revolution. Rome: Consultative Group on International Agricultural Research.

Iqbal, M. and M. Ahmad. 2005. Science \& Technology Based Agriculture Vision of Pakistan and Prospects of Growth. Islamabad: Pakistan Institute of Development Economics. 
Maass, G. 2003. Funding of Public Research and Development: Trends and Changes. OECD Journal of Budgeting. Paris.

Malik, S. 2015. Agriculture Policy in Pakistan. Islamabad: Pakistan Institute of Development Economics.

Napasintuwong, O. 2012. Survey of Recent Innovations in Aromatic Rice. Kasetsart University. Bangkok: Kasetsart University.

Organisation for Economic Co-operation and Development. 2011. Public Sector Research Funding. Paris: OECD Innovative Policy Platform. Paris.

Singh, R. 2010. Regional Report on Agricultural Research for Development in the Asia-Pacific Region. Rome: Global Forum on Agricultural Research and Innovation.

Usman, M. 2016. Contribution of Agriculture Sector in the GDP Growth Rate of Pakistan. Journal of Global Economics. Los Angeles. 


\section{Investment in Research and Development for Basmati Rice in Pakistan}

This paper presents the argument that Pakistan needs to increase its investments in agriculture research and development. It identifies strategies to show how a Basmati rice development program can achieve sustainable funding and effective oversight and implementation. Basmati rice is Pakistan's second-largest export earner but newer, long-grain, nonaromatic varieties have been cutting into its share of the premium rice market. The export value of Basmati rice has been impacted by leaf blight, trade practices, and market conditions. To address the issues, this paper argues that long-term vision and planning is needed, as well as a whole of government approach to help the value chain respond to present and future challenges.

\section{About the Asian Development Bank}

ADB is committed to achieving a prosperous, inclusive, resilient, and sustainable Asia and the Pacific, while sustaining its efforts to eradicate extreme poverty. Established in 1966, it is owned by 67 members48 from the region. Its main instruments for helping its developing member countries are policy dialogue, loans, equity investments, guarantees, grants, and technical assistance. 